\title{
A CLINICAL COMPARISON OF FLUOTHANE AND THE FLUOTHANE-ETHER AZEOTROPE
}

\section{VAN S. LAWRENCE, M.D. *}

THrs is a review of our experience with Fluothane and the Fluothane-ether azeotrope in 160 cases. It is not a controlled clinical study of these agents but rather an attempt to compare the two agents by carefully analysing the results of the routine use first of Fluothane then of the azeotrope.

There has been some controversy over the merit of adding ether to Fluothane. Hudon, Jacques and Boivin ${ }^{1}$ suggested that by adding ether to produce respiratory and myocardial stimulation many of the disadvantages of Finothane could be remedied. Their clinical experience supported this claim. Wyant, Merriman, Harland, Donaldson, and Wyant, Merriman, Kilduff and Thomas ${ }^{2,3}$ compared Fluothane with Fluothane-ether in human volunteers. Dobkin, Harland and Fedoruk ${ }^{4}$ compared their effects in dogs and both demonstrated that ether protected the subject from the cardio-respiratory depression of Fluothane. On the other hand, Johnstone, Evans and Murphy found that the substitution of the azeotrope for Fluothane consistently caused a deterioration of the patient's condition, and concluded that ether, rather than stimulating an adrenal response which would elevate blood pressure, caused further myocardial depression presumably because the sympatho-adrenal system was already depressed by Fluothane. Unfortunately, Johnstone et al. did not reverse the sequence to see if ether would produce the same myocardial depression if given with Fluothane for induction before the sympatho-adrenal system was already depressed. However, he did demonstrate that Fluothane, like sympathetic blockade, will block the organism's ability to protect itself from the depressing effect of ether if the Fluothane is given in adequate amounts before ether is given.

It seems apparent that the way in which these agents are used will determine to a great degree whether one has any advantage over the other. This study was performed in order to determine whether in our hands, with our patients, techniques, and personnel, one agent caused more hypotension than the other.

\section{Method}

Premedication for adults consisted of secobarbital 50-100 $\mathrm{mg}$. and atropine 0.4-0.6 mg. one hour and a half before induction. Meperidine, 25 to $50 \mathrm{mg}$., was used in the occasional patient who had pain before the operation. Appropriately smaller doses were given to children.

Fluothane or a $2: 1 \mathrm{v} / \mathrm{v}$ mixture of ether and Fluothane were given through the same vaporizer, a Fluotec, Mark II. A semi-closed circle system was used with 2L:2L flow of nitrous oxide and oxygen for adults; for patients under 6 years of

"Minnneapolis General Hospital, Minneapolis, Minn., U.S.A. 
age a non-rebreathing system was used. Thiopental was given in varying amounts to adults to supplement the induction but rarely used in children. Gallamine or succinylcholine was used as needed to provide muscle relaxation. On a few occasions meperidine was used to deepen the anaesthesia or to overcome tachypnea. Respirations were either assisted or controlled.

Fluothane was administered by residents, nurse anaesthetists and student nurse anaesthetists under close supervision of an anaesthesiologist in every case. The nurses had had no prior experience with Fluothane.

Table I summarizes the types of operations by anatomic regions. Fluothane or Fluothane-ether was the agent of choice in all cases ordinarily handled under general anaesthesia except those with preoperative hypovolemia or hypotension. Because Fluothane was used exclusively in one period of time and Fluothaneether in another, bias did not enter into the choice between them. It is conceivable that one series could have been weighted unconsciously in favour of better risk patients and, if so, the tendency would have been to use Fluothaneether in poorer risks.

All the patients anaesthetized with Fluothane, from its introduction into the department till Fluothane-ether was substituted for it, are included in the Fluothane series. Fluothane-ether was then used in the same way for another month and all the patients are included in the Fluothane-ether or "Azeotrope" series.

Eleven cases in the Fluothane series underwent more than one operation. Thus there are 108 cases listed for Fluothane in Table I and 97 cases in Tables II and III.

The anaesthetic and clinical records were reviewed by the nurse anaesthetists and the following facts were placed in a master record: (1) The name, age, sex, diagnosis, operation, anaesthetic agent, duration of anaesthesia, amount of thiopental and relaxant used. (2) The blood pressure response was recorded to show the change during induction. Another figure was then taken by inspection of the record for the average maintenance pressure. (3) In order to include those who exhibited transient drops in blood pressure during the case, the amount and kind of vasopressor used was recorded. The recording of the use

TABLE I

Optrations Performed

\begin{tabular}{|c|c|c|}
\hline & Fluothane & Azeotrope \\
\hline Head and neck and endoscopy & 38 & 27 \\
\hline Chest intrathorax & 3 & 1 \\
\hline Chest, extrathorax & 3 & 1 \\
\hline Upper abdomen & 25 & 15 \\
\hline Lower abdomen and pelvis & 14 & 12 \\
\hline Perineum, $G \mathrm{U}$ & 9 & 0 \\
\hline $\begin{array}{l}\text { Extremities } \\
\text { Skin grafts }\end{array}$ & 14 & 7 \\
\hline $\begin{array}{l}\text { Anaesthesia only-operation } \\
\text { cancelled because of trouble }\end{array}$ & 2 & 0 \\
\hline TOTAL & $108^{*}$ & 63 \\
\hline
\end{tabular}

${ }^{*} 97$ patients. 
TABLE II

Comparison of Hypotension* Rates by Age for Patrents Given Fluothane and Fluorhane-Ether

\begin{tabular}{|c|c|c|c|c|c|c|}
\hline \multirow{3}{*}{ Age Group } & \multicolumn{6}{|c|}{ Agent } \\
\hline & \multicolumn{3}{|c|}{ Fluothane } & \multicolumn{3}{|c|}{ Fluothane-Ether } \\
\hline & $\begin{array}{c}\text { No. } \\
\text { Patients }\end{array}$ & $\begin{array}{l}\text { No } \\
\text { Hypotensive }\end{array}$ & $\begin{array}{l}\sigma_{0}^{\prime} \text { Hypo- } \\
\text { tensive }\end{array}$ & $\begin{array}{c}\text { No } \\
\text { Patients }\end{array}$ & $\begin{array}{c}\text { No. } \\
\text { Hypotensive }\end{array}$ & $\begin{array}{l}\text { \% Hypo- } \\
\text { tensive }\end{array}$ \\
\hline $\begin{array}{l}0-15 \\
16-25 \\
26-45 \\
46-60 \\
61-70 \\
71-\end{array}$ & $\begin{array}{l}24 \\
14 \\
14 \\
20 \\
11 \\
14\end{array}$ & $\begin{array}{r}0 \\
4 \\
5 \\
12 \\
4 \\
7\end{array}$ & $\begin{array}{l}0 \\
29 \% \\
36^{\circ} \\
600^{\circ} \\
36 \% \\
50 \%\end{array}$ & $\begin{array}{r}18 \\
3 \\
9 \\
17 \\
111 \\
5\end{array}$ & $\begin{array}{l}0 \\
0 \\
2 \\
7 \\
4 \\
1\end{array}$ & $\begin{array}{c}0 \\
0 \\
22 \% \\
41 \% \\
36 \% \\
20 \%\end{array}$ \\
\hline Total & 97 & 32 & $34 \%$ & 63 & 14 & $22 \%$ \\
\hline
\end{tabular}

${ }^{*} \mathrm{H}$ ypotensive Classes $\mathrm{B}-\mathrm{F}$.

TABLE III

InCidence of Hypotension AcCording to SEverity

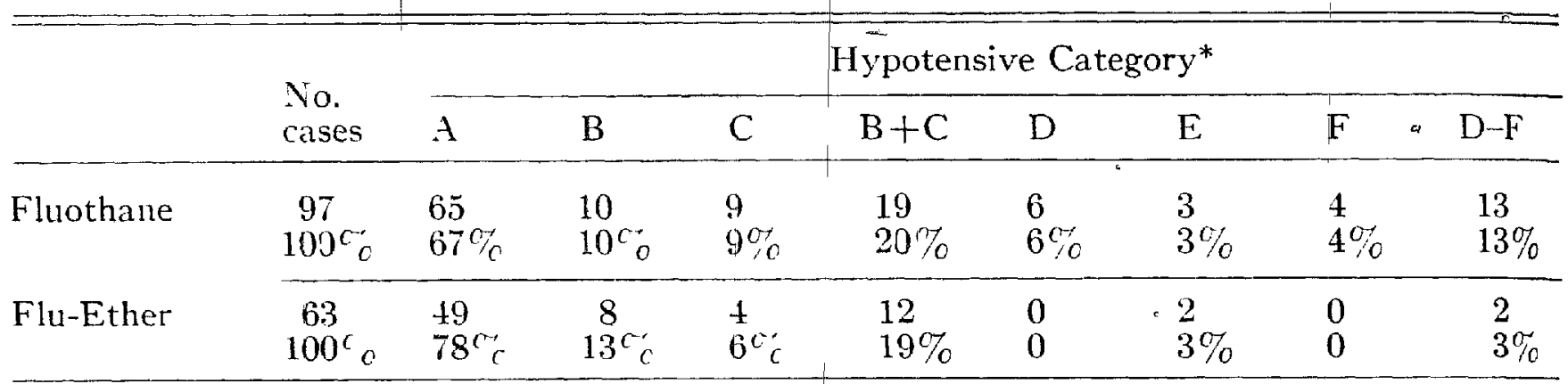

*For description of categories see text of article.

of vasopressors as an index of hypotensive episodes is justified because the indications for their use were standardized. Briefly, a vasopressor was used to correct hypotension when the hypotension was not caused by blood loss and when it did not respond readily to a lightening of the anaesthesia or the injection of atropine. Atropine 0.4 to $0.6 \mathrm{mg}$. was given intravenously whenever hypotension was associated with a slowing of the pulse. It was not recorded as a vasopressor. In general, a vasopressor was used sooner and therefore more frequently in patients with whom hypotension was a greater risk, but this variation in practice made it a fairly reliable index of the gravity of the hypotensive response.

After these figures were collected on a master sheet each case $/$ was classified according to the following formula:

Class A-There was no drop in blood pressure greater than 30 per cent of the pre-induction systolic pressure. No vasopressors used.

Class B-There was a drop in blood pressure greater than 30 per cent that responded without the use of vasopressors-maintenance pressure above 70 per cent of pre-induction level.

Class C-A vasopressor was used only once during the operation.

Class $\mathrm{D}-\mathrm{A}$ vasopressor was used more than once. 
Class E-The"maintenance blood pressure was allowed to remain at less than 70 per cent of the pre-induction level and no vasopressors were used.

Class F-Hypotension caused cancellation of surgery or substitution of another. agent.

Cases were put into only one of these categories. This classitication is an attempt to grade these blood pressure responses according to the gravity of the hypotensive response and the amount of difficulty they caused.

The postoperative complications and deaths were recorded on the master sheet. The clinical records of these cases were then reviewed and summarized by the author. The possibility of bias on the part of those reviewing the charts was minimized by the number, about 14, of different people involved and their general lack of any personal bias.

\section{Results}

The patients who developed any hypotension (classes B through F) are classified according to their age in Table II.

Children were remarkably resistant to the hypotensive effect of Fluothane. None of the 42 patients under 15 years became hypotensive (blood pressure less than 70 per cent of normal).

The highest incidence of hypotension for both agents was in the 45-60 age group. In those older than 60 the incidence was not as high but there is no apparent explanation for this other than statistical variation.

In Table III the cases are classified according to the degree of hypotension using the systems described above. When Fluothane was used 67 per cent of the patients fell in Class A (no significant hypotension) and where Flu-ether was used 78 per cent of the patients were in Class $A$.

Classes B and C represent a similar type of responsel and are differentiated mainly by the treatment given. In Class $B$ are the cases in which the blood pressure dropped but responded without a vasopressor and Class $\mathrm{C}$ are those who received a vasopressor only once. Although the use of a 'vasopressor suggests that the hypotension was of a graver import this may only reflect the anaesthetist's individual response. Therefore Classes B and C were totalled in a third column which shows no difference between the two agents.

The cases in which the hypotension was a major clinical problem are in Classes D, E and F. In these cases repeated vasopressors were needed, the hypotension though undesirable was tolerated, or the anaesthetic or the agent was discontinued. When Fluothane was the agent, 13 of the 99 cases developed hypotension of this magnitude while only 2 of the 63 cases with Fluothane-ether did. The Chi-squared test for comparison of rates yields a probability value less than 5 per cent for this difference.

\section{Complications and Deaths}

* Post-operative pulmonary complications occurred five times in patients receiving Fluothane and three times in those receiving Flu-ether. These were cases in which fever with râles, cough or pneumonia was noted in the progress notes. The other complications that occurred were not related to anaesthesia. 
There were 5 postoperative deaths in this series, none of which was related to anaesthesia.

\section{Side Effects}

Tachypnea was frequently encountered but was not consistently recorded so that no difference between the agents could be deduced.

In two instances not in this series persistent coughing occurred with the use of Flu-ether but stopped when Fluothane was substituted for it.

\section{Discussion}

The children in this series were uniformly resistant to any hypotensive effect of Fluothane or Flu-ether, but 30 to 44 per cent of the patients over 15 years became hypotensive at least once in the course of the anaesthetic. The fact that thiopental was used infrequently with those under 15 may have contributed this

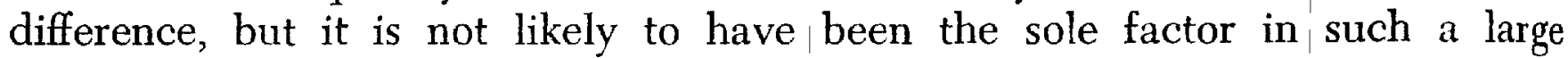
difference.

The main difference between Fluothane and Flu-ether became apparent when those who exhibited a transient drop in blood pressure were separated from those in whom hypotension recurred frequently or was a persistent problem. Both agents produced a similar incidence, 19-20 per cent, of transient hypotension but with Fluothane there was a significantly increased incidence of troublesome hypotension throughout the case.

It is doubtful whether this difference in incidence of hypotension was due to an increasing skill on the part of the anaesthetists, because those who administered the agents rotated frequently through the department and had little opportunity to be involved to any great extent in both series. Rather, it seems apparent that the lower incidence of troublesome hypotension was due to a difference between the agents. The well-known ability of ether to stimulate a sympatho-adrenal response which is sufficient to overcome the myocardial depression of ether alone in light planes of surgical anaesthesia must be the factor that protects the patients who receive Fluothane. Dobkin demonstrated this protection by comparing various cardio-respiratory parameters when dogs were given either 2 per cent Fluothane or 3 per cent Fluothane-ether. The concentration of Fluothane was the same in both series and the ether still prevented much of the cardio-respiratory depression of Fluothane.

There is no doubt that Fluothane is a safe agent in the hands of the experienced administrator. In fact, there is some evidence that the very mechanisms that lead to hypotension actually are of benefit to the patient who is in danger of shock $^{5,6,8}$ and although many studies ${ }^{9,10,11}$ have failed to demonstrate ganglion blockade objectively, there is a growing store of clinical reports ${ }^{5,6,12,13}$ describing what seems to be a protection by Fluothane from the adverse effects of the sympatho-adrenal response to stress.

If ether then stimulates a sympathetic response it is logical to assume that it thereby nullifies the "anti-shock" effect of Fluothane by provoking just the type of reaction that Fluothane is thought to depress. Therefore, if Fluothane is to be nsed with this "anti-shock" nurnose in mind. it is nrobahlv contradistorv to add 
ether to it. However, if the anaesthetic must be administered by one who is not well rversed in the finer nuances of Fluothane, or to whom the debated advantages of an "anti-shock" effect are less real than the dangers of persistent hypotension, then the Fluothane-ether azeotrope appears to be the safer agent.

\section{SUMMARY}

The incidence of hypotension in 160 Fluothane or Flu-ether anaesthetics was analysed according to the agent given and the age of the patient. Both agents produced a transient hypotension in about 20 per cent of the cases but Fluothane produced a significantly higher incidence of troublesome, persistent or recurrent hypotension than did Fluothane-ether. Neither agent caused hypotension in patients under 15 years of age.

\section{RÉSUMÉ}

On a affirmé que le mélange azéotropique fluothane et éther diéthylique possédait plusieurs avantages que le fluothane seul n'avait pas. La plupart de ces avantages, on le croyait, tenaient à la capacité de l'éther de pouvoir provoquer une stimulation sympathico-surrénalienne qui surmontait la dépression cardiovasculaire produite par le fluothane. Toutefois, récemment, un autre chercheur a trouvé que lorsqu'il remplaçait le fluothane par le mélange azéotropique, il s'ensuivait une dépression cardio-vasculaire importante. Selon toute apparence, l'éther déprimait le système cardio-vasculaire parce que ses défenses avaient été paralysées par l'usage antérieur du fluothane.

Pour pouvoir préciser lequel de ces agents, dans notre service, a produit le plus d'hypotension, nous avons étudié les dossiers d'anesthésie de 160 malades qui avaient reçu de routine ces anesthésies: 97 du fluothane, et 63 le mélange fluothane-éther. Nous avons employé le fluothane durant un certain temps et le mélange durant une autre période.

A la fin des séries, nous avons étudié tous les dossiers, et nous avons classifié chacun des cas selon le degré d'hypotension qu'il avait présenté. Nous avons fait cinq classes:

La classe A comprenait les cas où la tension artérielle n'avait pas baissé plus de 30 pour cent de ce qu'elle était avant l'induction.

Les classes $\mathrm{B}$ et $\mathrm{C}$ comprenaient les cas ayant présenté une chûte transitoire de la tension.

Les classes $\mathrm{D}, \mathrm{E}$ et $\mathrm{F}$ comprenaient les cas où il a été nécessaire de donner, à répétition, des vasopresseurs, l'hypotension étant continuelle mais tolérée, et les cas où l'agent ou la chirurgie ont été abandonnés à cause de l'hypotension.

Si l'on compare la fréquence des différentes réponses hypotensives entre les deux agents, il n'y a pas de différence en ce qui concerne la fréquence des hypotensions transitoires s'abservant à l'induction. Toutefois, le fluothane seul a entraîné beaucoup plus souvent que le mélange, une hypotension marquée, persistante et ennuyeuse. Chez les malades au-dessous de quinze ans, ni l'un ni l'autre de ces aqents n'a nrovonué d'hvootension imoortante. 


\section{REFERENCES}

1. Hudon, T., Jacques, A., \& Borvin, Paul A. Fluothane-ether: An Azeotropic Mixture. Canad. Anaes. Soc. J. 5: 403 (1958).

2. Wyant, Gordon; Merriman, John E.; Harland, J. H.; \& Donaldojon, H. V. The Cardiovascular Effects of Azeotropic Halothane-Ether. Canad. Anaes. Soc. J. 7: 91 (1960).

3. Wyant, Gordon M.; Merriman, J. E.; Kilduff, C. J.; \& Thomas, E. T. The Cardio. vascular Effects of Halothane. Canad. Anaes. Soc. J. 5; 384 (1958).

4. Dobkin, A. B.; Harland, J. H.; \& Fedortuk, S, Comparison of the Cardiovascular and Respiratory Effects of Halothane and the Halothane-Diethyl Ether Azeotrope in Dogs. Anesthesiology 21: 13 (1960).

5. Johnstone, Michael. Human Cardiovaspular Response to Fluothane. Brit. J. Anaesth. 28: $392(1956)$.

6. Johnstone, Mrchaet. The Role of Halothane in the Prevention of Surgical Shock. Brit. J. Anaesth. 30: 435 (1958).

7. Johnstone, Michael, Evans, Vincent, \& Murphy, Patruck V. The Halothane-Ether Azeotrope: An Illogical Mixture. Canad. Anaes. Soc. J. 8: 53 (1961).

8. Raventos, J. The Action of Fluothane: A New Volatile Anaesthetic. Brit. J. Pharmacol, 11: 394 (1956).

9. Beaton, A. C. Fluothane and Hypotension in Cats. Canad. Anaes. Soc. J. 6: 13 (1959).

10. Severunghaus, J. W., \& Cullen, S. C. Depression of Myocardium and Body Oxygen Consumption with Fluothane. Anesthesiology 19: 165 (1958).

11. Millar, R. A., \& Morris, M. E. Induced Sympathetic Stimulation during Halothane Anaesthesia. Canad. Anaes. Soc. J. 7: 423 (1960).

12. Dechêne, J.-P., \& HÉBert, Claude. Fluothane-Ether in Anaesthesía for Pulmonary Surgery. Canad. Anaes. Soc. J. 7: 100 (1960).

13. Hartung, L. Fluothane in Thoracic Surgery: A Study of 500 Cases. Anesth. et analg. 15: 932 (1958). 